\title{
The interplay between formal and informal elements in analysing situations of role conflict among construction participants
}

Article

Accepted Version

Kabiri, S. and Hughes, W. (2018) The interplay between formal and informal elements in analysing situations of role conflict among construction participants. Construction Management and Economics, 36 (12). pp. 651-665. ISSN 0144-6193 doi: https://doi.org/10.1080/01446193.2018.1472794 Available at https://centaur.reading.ac.uk/79044/

It is advisable to refer to the publisher's version if you intend to cite from the work. See Guidance on citing.

To link to this article DOI: http://dx.doi.org/10.1080/01446193.2018.1472794

Publisher: Taylor \& Francis

All outputs in CentAUR are protected by Intellectual Property Rights law, including copyright law. Copyright and IPR is retained by the creators or other copyright holders. Terms and conditions for use of this material are defined in the End User Agreement.

www.reading.ac.uk/centaur 
Central Archive at the University of Reading

Reading's research outputs online 


\title{
The interplay between formal and informal elements in analysing situations of role conflict among construction participants
}

\author{
The interplay of formal and informal factors in construction teams influences the \\ enactment of roles and the individuals who fulfil those roles. With a specific \\ focus on a phenomenon called role conflict, the aim is to explore if and how the \\ interaction of formal and informal elements would lead to situations of role \\ conflict. This phenomenon proved to lead to frustration, tension and employee \\ burnout. An analytical model of role interaction was developed, which \\ disentangles formal and informal elements that shape role interactions. \\ Qualitative data was collected through semi-structured interviews, project \\ documents and observations. Four cases of role conflict are presented here. \\ Contract, as a formal element, and participant's values and interests, as informal \\ elements, appeared to be the most important factor shaping participants' \\ expectations and behaviours. The analysis in this study showed that if a \\ participant who faces role conflict is able to influence the formal elements in \\ favour of his or her informal elements, then he or she may experience less \\ frustration. At a more general level, the results suggest that increasing formality \\ can increase participants' frustration, which then would decrease the likelihood \\ of collaboration. As the theoretical contribution, this research extends \\ organisational role theory to deal with informal and formal aspects. Taking into \\ account formal sources enables the study of how roles are institutionally \\ governed while including informal sources allows for the idea that some of the \\ aspects of the role, even in the context of work role, are socially constructed.
}

Keywords: formality; informality; role conflict; role; expectation.

\section{Introduction}

Roles in construction projects are diverse and cover a wide range of issues. Some roles come about because of the way that the market operates, some because of the needs for governance and some have become institutionalized through the development of professional institutions. What makes this more complex is that the task of construction continues to develop and grow more complex, so the diversity of roles continues to 
grow as new roles emerge in response to new technologies and new social, business, economic and cultural imperatives. An interesting phenomenon in relation to all of these roles is the interplay between the formal definitions of roles and informality in the way that they are enacted. This interesting empirical question is the focus of this paper. Indeed, approaches for further formalization of roles and responsibilities with the aim of increasing collaboration have been criticized for not properly considering the lived realities of construction participants (Seymour and Rooke 1995, Dainty et al. 2007).

Researchers have been studying informality in several contexts such as partnering (Bresnen 2009, Gottlieb \& Haugbølle 2013), knowledge sharing (Mueller 2015), control and empowerment (Tuuli, Rowlinson and Koh 2010) and roles and professionals (Gluch 2009 and Georg and Tryggestad 2009). These studies share the idea that informal elements influence construction practices in several ways. Despite the growing body of research on informality, the interplay between formal and informal practices is still not well understood and calls for further, theoretically-informed investigation. This research explores enactment in the interplay between formal and informal practices in the context of misaligned expectations; a phenomenon that is, theoretically, called role conflict. Unlike conflict between people, internal conflict arising from within a person's role is rarely, if ever, productive.

Despite extensive research in several disciplines, role conflict is a phenomenon that has not been addressed in the construction management literature. In this research, instances of role conflict are used to analyse the way that formal and informal practices inform participants' expectations and behaviour, and what consequences this may have. Identifying and acknowledging different formal and informal practices in construction projects will provide a platform for a better understanding of the way expectations emerge. This shall allow informed decisions to adjust behaviours and path the way for 
higher levels of collaboration. Should participants be able to explain why they have an expectation (or a set of expectations) from another participant in the team and why they behave in a certain way, barriers for a collaborative interaction could be identified, discussed and then removed. Thus, the acquisition of this knowledge should benefit the stakeholders and, eventually, the project.

\section{Research into formal and informal aspects of roles in construction projects}

Gluch (2009) focused on one specific role, the environmental professional, a newly emerging role in Swedish construction projects. She explored the conflict between formal and informal practices for these professionals. The problem she focused on was, partly, the frustration of environmental professionals in the communication of information to other members of a project organization. Her analysis showed that environmental professionals need to deal with situations in which their 'personal beliefs and ideology' conflict with the 'production-focused and time-pressed agenda' of construction project practice. To deal with such situations, environmental professionals adopt a formal role in line with their job description and an informal role suitable for that special project. The need to conform to formal and informal expectations separately and in different ways puts extra pressure and stress on environmental professionals. "Dual identity" was pointed out by these officials as a problem. Gluch concluded that "contradictory practices prevent environmental professionals from fulfilling their expected role and function" (p. 959). There is no reason to suppose that this issue is unique to this professional group.

Another study focusing on formal and informal aspects of roles was carried out by Georg and Tryggestad (2009) with a specific focus on the role of the project manager. These authors argued that project managers' tasks are not clearly defined in construction projects; while they should keep an eye on time and cost issues, they need 
to manage relationships as well as team culture, values and motivations. By assuming that the budget shapes the role of the project manager, Georg and Tryggestad criticized the prevailing presumption that roles are "relatively stable and dictated by contracts and/or cultural relations" p.969.

The above studies focused on the interplay between formal and informal for a specific role. In particular, they highlight that roles tend not to be as stable and clearly defined as we might like to think. This indicates that role conflict should be expected in construction projects. This phenomenon is the focus of our research. In this research, through the lens of organisational role theory, the focus is on individuals who experience role conflict as a result of the conflict between and within formal and informal elements in construction project practice.

\section{Organisational role theory as the theoretical background}

Role theory compares social life with the theatre where actors play predictable roles. It rests on three key concepts:

- "patterned and characteristic social behaviours";

- "parts or identities that are assumed by social participants" and

- "scripts or expectations for behaviour that are understood by all and adhered to by performers";

these are called "role", "social position" and "expectation", respectively (Biddle 1986, p. 68). It is about the behaviour that people associate with a role and then expect that from the individual who enacts the role. Organisational role theory focuses on roles that individuals enact in social systems (Wickham and Parker, 2007). Within that social system, sources of expectations would be written scripts or non-written norms. Individuals within an organisation are expected to comply with the behaviour that is 
assigned as their work roles - roles taken within the organisation. Based on this, the concept of role conflict will be introduced using a model of role interaction, providing the basis for the analysis of the empirical cases.

\section{Role conflict as a concept in organisational role theory}

One of the main phenomena discussed in organisational role theory is role conflict (Gross et al. 1958; Kahn et al. 1964). Role conflict is driven by the assumption that, there are conflicting norms within organizations. Should the members of the organisation face such opposing norms, they may struggle to enact their role; this implies a situation of role conflict. In other words, an individual may face role conflict if his or her compliance with one norm or expectation would lead to the ignorance of some other norms or expectations. An example of role conflict for a digital engineer is when the management of a company expect the digital engineer to implement new technologies but the people who would actually need to be familiar with such technology resist the change. In this research, role conflict will be studied from three aspects:

(1) The causes behind role conflict.

(2) The consequences of this phenomenon on individuals.

(3) The way each individual may deal with such situation.

One of the most comprehensive studies focusing on the nature, causes and consequences of role conflict was carried out by Kahn et al. (1964); indeed, these researchers were pioneers in publishing research on this phenomenon. They linked the rapid changes of technology and increasing importance of large scale organisations with situations of role conflict for the labour force and how this affects their physical and mental health. 
Kahn et al. (1964) carried out a national survey among 725 male workers in the US workforce. They also interviewed 53 individuals from six industrial locations. Based on the national survey, they revealed that almost half of participants were facing noticeable role conflict and, among them, $15 \%$ reported this issue as a serious and frequent problem. Furthermore, 39\% of the sample reported being bothered by the fact that they had not been able to satisfy conflicting demands of their role senders. The findings of Kahn et al. (1964) showed that role conflict may have negative emotional experience on the focal person and this includes increased tension, high internal conflicts, decreased job satisfaction, and reduced confidence in superiors and in the organization as a whole.

Over the decades, a huge amount of research into role conflict within different disciplines has focused on the consequences of this phenomenon on individuals. Research in healthcare organisations showed that emotional exhaustion, depersonalization and stress were some of the consequences of role conflict (Piko 2006, Ahmady et al. 2007, Soltani et al. 2013). As Diebig, Bormann, \& Rowld (2017) discusses, role conflict represents a so-called job demand due to its association with physiological and psychological costs leading to exhaustion and impaired health (Lee and Ashforth, 1996; Nixon et al., 2011). In the field of business studies similar effects were explored. Tang and Chang (2010) demonstrated a negative effect on employee creativity due to role conflict. Uetschy Murfield et al. (2016) explored the implications of role conflict as a result of opposing perspectives and goals in customer-supplier relationships. These researchers showed that expectations outside of the suppliers' contracts can have detrimental effects on the suppliers' relationships with customers. Consequently, their willingness for future accommodations of customers' requests would be affected. 
The results of the above research are in line with early studies on role conflict. More specifically, earlier research (Van Sell, 1981; Jackson and Schuler, 1985; Netemeyer, Johnston and Burton, 1990) shows that role conflict increases job tension, job dissatisfaction and employee burnout and decreases organizational commitment and performance. Floyd \& Lane (2000) showed that role conflict increases uncertainty and the risk of opportunistic behaviour. It also damages the quality of information exchange between managers and hinders any adaptive processes. This is clearly a serious issue in all walks of life which has not been solved in spite of being the topic of research in several disciplines for decades. Role conflict specifically in construction project organisations, with their unique temporary multi-dimensional nature, has hardly been the focus of any research (Kabiri, Hughes and Schweber, 2014; Kabiri, 2015).

The second aspect of research into role conflict revolves around identifying situations that may lead to the occurrence of such phenomenon. Little research explored this aspect of role conflict within organisations. Teh et al. (2009) investigated the effects of total quality management (TQM) practices within Malaysian manufacturing and service firms on employees' experiences of role conflict. These authors have used the six TQM constructs (leadership, strategic planning, customer focus, human resource focus, process management and information analysis) as the potential sources of role conflict. They based their survey questions on these constructs. Analysing 433 responses from 98 different firms in manufacturing and service industries, Teh et al. (2009) concluded that, among six TQM practices, leadership, process management and information analysis have a significant effect on employee's experience of role conflict. The third aspect of research into role conflict is related to the way individuals, who face role conflict, resolve the situation and cope with its consequences. Kahn et al. 
(1964) showed that, in such situations, individuals may take different strategies such as social and psychological withdrawal.

What these studies show is that the causes of role conflict, its effects on different people and their reactions to such situations are pervasive. To resolve negative impacts of role conflict, some researchers suggest an informal, flexible and autonomous work environment (Katz and Kahn 1978, Raphael 1965), while others encourage more formalization in the organization (Kahn et al. 1964, Rizzo et al. 1970). One could conclude that the first suggestion is to have more informal and less formal environment within the organization whilst the second one suggests the opposite. This creates the space to investigate the interplay between and within formal and informal practices in situations of role conflict. It is the tension between these two views that defines our study. This would fall more in the second aspect of role conflict, which is around the underlying situations and reasons leading to role conflict. However, the first and the third aspects of role conflict will also be explored accordingly.

\section{The model of role interaction taking into account formal and informal elements}

To study the interplay between and within formal and informal practices in situations of role conflict, the classic model of factors involved in role conflict (Kahn et al 1964) was modified (Figure 1) and used. The new model is to draw attention to the interaction between two or more project participants to study whether the sources informing their role expectations and behaviour were formal or informal. This happens through the introduction of four elements of "formal sources of role expectations", "informal sources of role expectations", "formal sources of role behaviour" and "informal sources of role behaviour" to the classic model of role conflict (Kahn et al 1964). Such analysis provides a basis to examine misalignments in role expectations and thus helping to explain individuals' behaviour. 


\section{Sources of Role expectation}

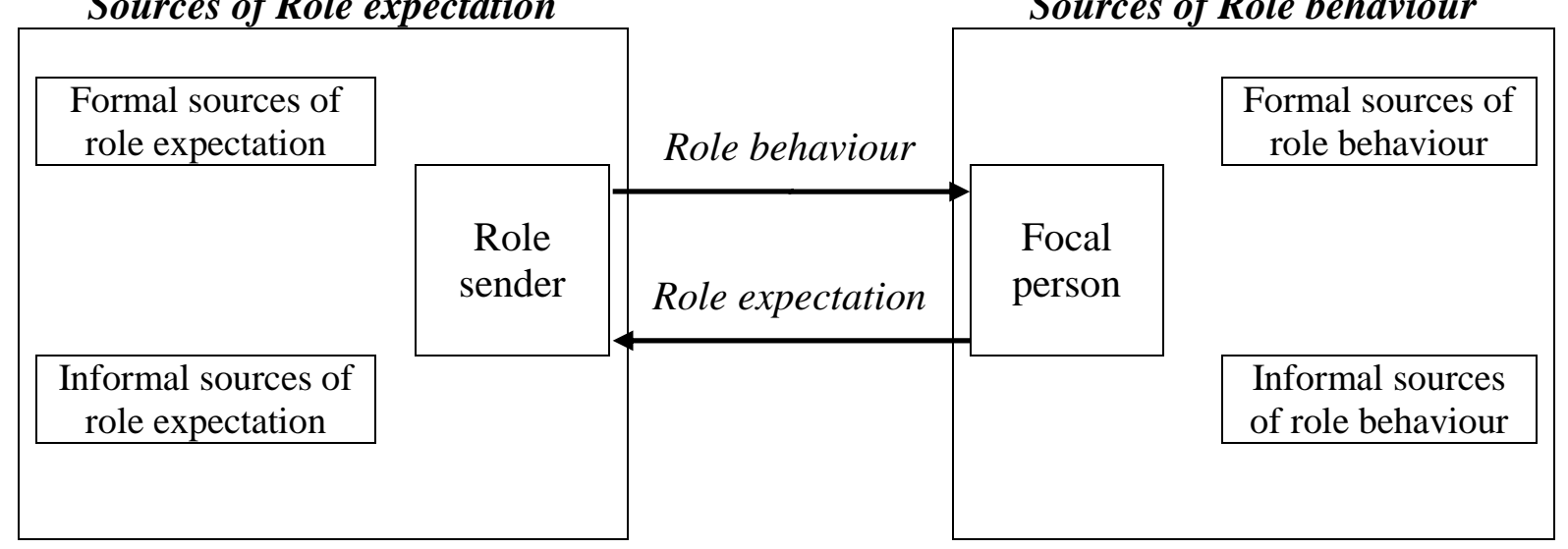

Figure 1: The model of role interaction considering formal and informal sources of role expectation and role behaviour

Table 1 provides definitions of the main concepts used in the model of role interaction.

'Sources of role expectation' involve several formal and informal elements that influence the expectations of the role sender and 'Sources of role behaviour' reflect several elements that would influence the behaviour of the focal person. The arrow of 'Role expectation' shows the communication of the expectation(s) and the arrow of 'Role behaviour' represents the response of the focal person; it informs the role sender of the degree to which the focal person conforms to role expectations at one point in time, which then influences the expectations later in time. In other words, the emergence of a role expectation, its communication to the focal person, the emergence of a role behaviour and the relevant response to the role sender form a loop; a cyclic and on-going process. Over time, role sender's expectations and focal person's behaviour may change as a result of this cyclic process, which essentially allows people to learn and adapt to changes. Applying this model, not only allows the study of such processes in construction teams, but also provides a platform to reflect on several formal and informal elements that inform expectations and behaviours of participants. 


\begin{tabular}{|c|c|}
\hline Concept & Explanation \\
\hline Role & $\begin{array}{l}\text { Roles are standardized patterns of behaviour that are required of all individuals } \\
\text { in the context of their relationship with others. Those patterns of behaviour are } \\
\text { expected regardless of individuals' wishes or their interpersonal relationships } \\
\text { outside of the functional relationship (Katz \& Kahn, 1978). For example, in an } \\
\text { architectural company, a general set of patterns of behaviour is required of all } \\
\text { the ones enacting the role of the architecture. Whilst there may be differences in } \\
\text { terms of the tasks that each individual carries out, they are supposed to fall into } \\
\text { the institutional definition of the role. }\end{array}$ \\
\hline Focal person & $\begin{array}{l}\text { The person whose role behaviour is under consideration is called the focal } \\
\text { person. In the example of the architectural company, one of the architects could } \\
\text { be the focal person (Kahn et al1964). }\end{array}$ \\
\hline Role sender & $\begin{array}{l}\text { Role senders are people who communicate a role expectation to the focal person } \\
\text { (Rommetveit, 1955). In the above example, the architect's line manager, a } \\
\text { detailer within the organisation who works with the architect and a structural } \\
\text { engineer and a quantity surveyor outside of the company are some of the } \\
\text { architect's role senders. }\end{array}$ \\
\hline Role expectation & $\begin{array}{l}\text { Role expectations involve the role sender's preferences regarding a task, } \\
\text { personal characteristics or style of the focal person; they may deal with what } \\
\text { kind of person the focal person should be, what he/she should think or believe } \\
\text { and how to relate his/her tasks to others (Kahn et al 1964). In our example in the } \\
\text { architectural company, the line manager assigns the architect the task of } \\
\text { designing a building for a client. The manager then expects the architect to carry } \\
\text { out an appropriate design whilst reflecting on the client's needs. The detailer } \\
\text { expects the architect to provide sufficient information to ease the detailing. The } \\
\text { structural engineer expects the architect to be flexible about the design, should it } \\
\text { require unnecessary or costly structural solutions. At the same time, the quantity } \\
\text { surveyor expects the architect to consider the cost limits of the project in the } \\
\text { design. As is clear from this example, role expectations can be communicated } \\
\text { from senders inside and outside the organization. Moreover, they may be } \\
\text { initiated from written and formal documents or from non-written norms. }\end{array}$ \\
\hline Role behaviour & $\begin{array}{l}\text { Role behaviour is the kind of behaviour which is relevant to the system, } \\
\text { performed by the focal person as a member of the system, but is not necessarily } \\
\text { in line with the role expectations of his/her role senders (Kahn et al 1964). In the } \\
\text { above example, designing the building by the architect in the architectural firm } \\
\text { is his role behaviour. More specifically, taking into account the instructions of } \\
\text { the line manager, sketching the design, providing information for the detailer } \\
\text { and the structural engineer while having an eye on the costs of the design are } \\
\text { several role behaviours associated with the role expectations. Yet, if the } \\
\text { architect provides a design with a higher cost than predicted, the design is still } \\
\text { the architect's role behaviour. }\end{array}$ \\
\hline Formal sources & $\begin{array}{l}\text { Formal sources of role expectations and role behaviour in the context of } \\
\text { construction projects include, but not limited to, written contracts, codes and } \\
\text { standards, plans of works and organizational factors (Kabiri 2015). }\end{array}$ \\
\hline Informal sources & $\begin{array}{l}\text { Informal sources of role expectations and role behaviours include, but not } \\
\text { limited to, work experience, educational background, stereotypes, interpersonal } \\
\text { factors, fears, sensitivities, motives and values (Kabiri 2015). }\end{array}$ \\
\hline Role interaction & $\begin{array}{l}\text { The process of sending role expectation by a role sender, receiving the role } \\
\text { expectation by the focal person and responding through a role behaviour is } \\
\text { called role interaction. This process is considered as the unit of analysis for the } \\
\text { research (Kabiri 2015). }\end{array}$ \\
\hline Role conflict & $\begin{array}{l}\text { If the role expectations communicated to the focal person are not compatible to } \\
\text { the extent that compliance with one role expectation would mean ignoring or } \\
\text { opposing another role expectation, the focal person may be in the situation of } \\
\text { role conflict (Kahn et al 1964). In the case of the architect, if the line manager } \\
\text { pressures the architect to issue a set of drawings as soon as possible and, at the } \\
\text { same time, the detailer, who prepares the drawings, requests an extension of the } \\
\text { deadline then the architect faces role conflict; the pressure from the line } \\
\text { manager conflicts with the pressure from the detailer. }\end{array}$ \\
\hline
\end{tabular}

Table 1: Definitions of the main concepts in the model of role interaction 


\section{Research design and methodology}

The purpose of the empirical work was to examine in some detail the formal and informal elements of role interactions in some specific situations. While there are interesting reports of survey questionnaires and a lot of theorizing around role conflict, there was an opportunity to move the debate forward with a forensic examination of some instances of role conflict. Indeed, looking at this phenomenon as a process of role interactions over time (communicating role expectations and receiving role behaviours) calls for an exploratory research design with qualitative data. This provides the platform to explore vignettes of role conflict when actors (construction participants in this study) justify their expectations and behaviours using different formal and informal sources.

Three projects of various sizes were studied. There was no attempt to generalize any sets of results based on the size or type of projects. Hence, the projects were not connected in any particular aspect. The aim was to explore situations of role conflict without trying to compare/contrast the projects. For the purpose of this research, the anonymized projects are referred to as the Green, Yellow and Blue project. The Green project was for a new energy centre and an underground district heating mains system. The Yellow project was an extension of a hospital to build new wards and an expanded intensive care unit. The Blue project was to open a new branch of a bank building, which was primarily to remodel an existing building without any major structural alterations. However, it involved architectural, mechanical and electrical design.

The primary selection criteria for identifying participants for this research were based on the principles of organisational role theory that lay behind the investigation. More specifically, participants enacting dominant roles, along with their major role senders, were identified and interviewed. Major role senders are defined as people who are, in the context of the project, have a major effect on the enactment of the role of the 
focal person by communicating their expectations to him/her. Figure 2 shows an organogram of the interviewees in the Green project, just as an example, to demonstrate how some of the dominant roles and their major role senders are linked.

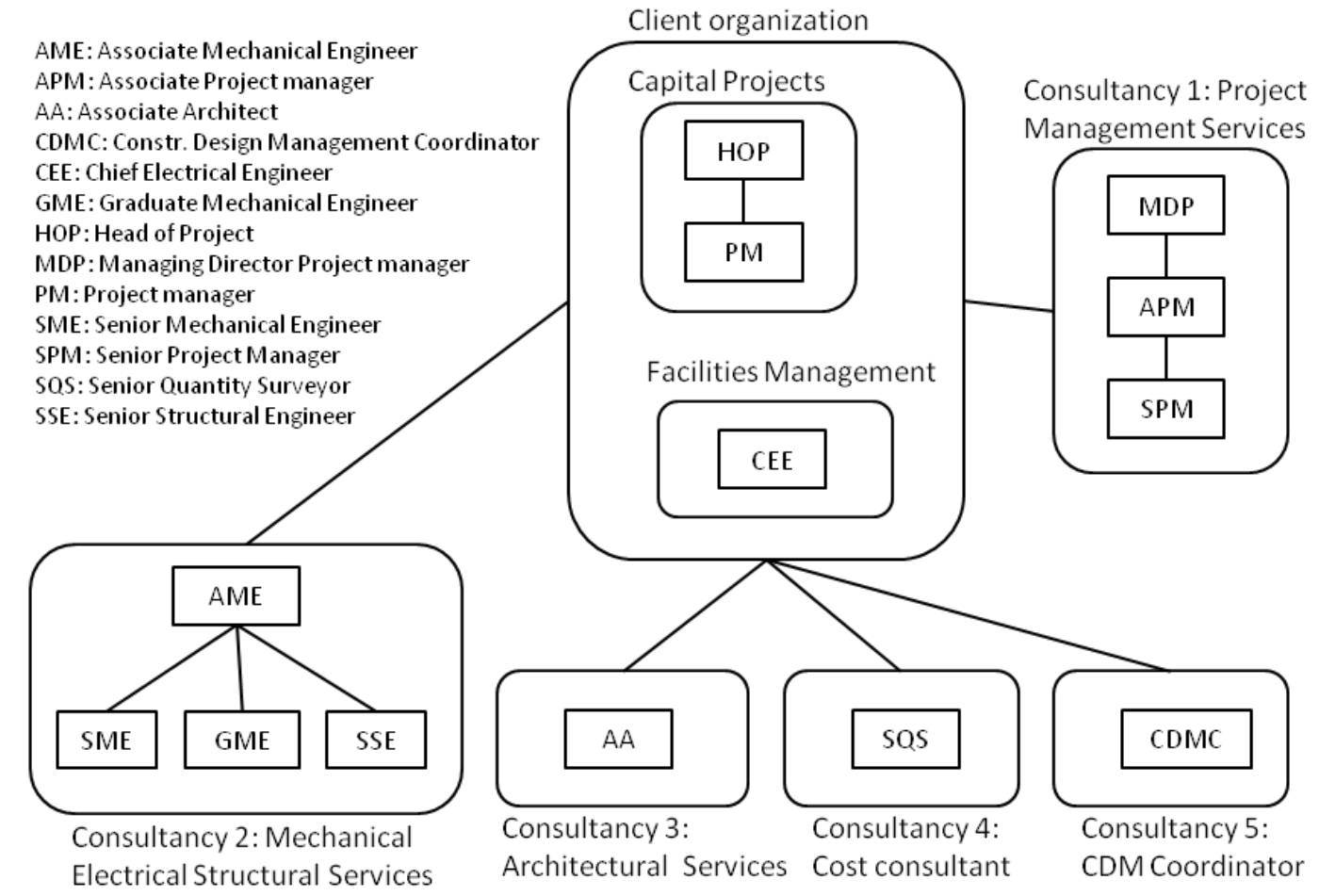

Figure 2: Organogram of the interviewees in the Green project

Interviews are widely used method of data collection particularly in qualitative research (Bryman 2012). The main source of data was through interviews, but, in addition, the minutes of the project meetings, including the ones held before the involvement of the authors with the project, were studied thoroughly. This was to flag any potential issues leading to the emergence of expectations by a member along with the relevant responses from other members of the team. In line with that, some project meetings were observed to spot the extent of debate or controversy and the behaviours of the people in the situation. The contracts of several parties were also reviewed. (As is typical in the construction sector, each participant in the design process is contracted in from a firm of specialized consultants.) The interview data fed directly into the analysis 
and other sources were extremely helpful to build the scene of a role interaction (vignette) and to follow several issues over time.

Before carrying out the interviews, an interview guide was developed which was targeting three different levels; individual, company, and project. The most important aim was to explore if participants faced role conflict in their work role. To do so, a few strategies were taken. In the interviews, the interviewees were asked about the main roles with whom they interact the most. Topics and challenges in the design and project team meetings were also brought up in the course of the interviews, should they seem to provide relevant information. A total of 33 interviews with 23 people, with an average duration of 50 minutes, were carried out. All the interviews were recorded and transcribed verbatim.

One of the main and foremost approaches taken in this research to minimise the bias in data collection was to ask the interviewees indirect questions. More specifically, instead of asking about role conflict, questions were targeting the interviewees' tasks. For example, to explore any potential mismatches among role expectations, one of the questions was whether they would change any of their tasks, should they be able to do so. Such questions would not imply any particular bias from the interviewer as any answer could be relevant.

To minimise bias in the interpretation process, the impressions of the respondents were continually re-evaluated and the previous assumptions about role conflict were challenged. For example, little previous studies focused on the effects of a situation of role conflict on role senders. In this research, negotiations of role senders to receive the expected role behaviour and the effects of such situations on them were also analysed. Indeed, disentangling the data to explore the situations of role conflict was one of the main processes in the analysis, which allowed a symmetrical analysis of the 
interaction rather than a sole focus on the focal person. This helped in minimising confirmation bias in handling the data.

\section{Limitations and ethical issues in data collection}

The limitations of the approach to this research may be considered from two perspectives: limitations around the data collection and limitations related to role theory. As for data collection, the first issue is related to the boundaries of the research. The focus of this research was on expectations and behaviours related to the work role. More specifically, the potential effects that extra-occupational elements might have on participants' behaviours were excluded. For example, one of the project managers explained that he was required to carry out his very demanding day to day tasks at work, but also need to look after his three kids on the weekends. His case was a potential instance of role conflict, but the tension between the role of an employee and a father. Despite the very effects of such situations on individuals' behaviours and productivity, exploring on such cases would divert the focus of the research which was on formal and informal aspects of work role. This was to set practical boundaries to the empirical work and to keep the findings focused on the empirical situation that was observed.

The second limitations on data is that, in some instances of role conflict, access to the role sender/senders was not possible. As a result, the analysis of those instances were primarily based on the focal person's perception of the situation. The argument to justify this limitation is that although the case would have been richer in terms of the information from both sides of the interaction, it would not have changed the situation of role conflict for the focal person. The third limitation on the data is related to observing the consequences of instances of role conflict on the individual and the team. The analysis of the consequences of this phenomenon for some instances was primarily 
based on participants' explanations and impressions from the situation rather than the researchers' own observations.

Limitations of the research which are related to role theory are mainly due to the confusions and disagreements leading to criticism on role theory. The controversy around role theory relates to several factors such as various definitions of the term 'role' (Biddle, 1986), its theatrical metaphor, which is not 'synonymous' with social acting (Schreyägg \& Häpfl 2004, Goffman 1959, Mangham 2005), and its inadequacy for considering the process in which individuals learn about, adapt to and effect a role performance over time (Lynch 2007, Callero 1994). To deal with these limitations, and to provide clarity within the research, a clear definition of all of the terms in this study was provided (Table 1). In addition, by using role theory in this research, the attempt is not to overlook the differences between a theatrical scene and real life, and certainly not to oversimplify real life. The lens of organisational role theory and the model of role interaction allow the study of interplay between several formal and informal sources as causes of role conflict within organisations.

\section{Organisation of the data and analytical methods}

The structuring of the data was based on several elements of the model. In some cases, symptoms of role conflict was noted in the interview when the interviewee was describing a role interaction/vignette, whilst in some other cases, the situation was explored by combining and connecting data from several sources relating to a potential vignette of role conflict. Should there be any role conflict, the role expectation and role behaviour of the parties involved in the role interaction were noted and formal and informal sources that influenced the role interaction were explored. The ultimate aim was to build the vignette, like a jigsaw puzzle, using several types of data including interview material, minutes of the past and current meetings, notes from observation of 
project meetings and project contracts. These were chunks of data allocated under the relevant coding node in NVivo.

Based on that, the list of formal and informal sources that initially developed through literature review was extended. The effect of the situation of role conflict on both (or even more) parties in the interaction was explored/noted and the approach to negotiate/resolve the situation was further studied. One of the reasons to interview some participants more than once was to extract further information related to such episodes.

The data was electronically stored, indexed and organized. All documentary evidence was read thoroughly several times and annotated with memos. The data was then coded. This involved a continuous iteration between the theoretical issues and the data (Bryman, 2012) . The initial coding was based on the concepts in the theoretical perspective (King, 1998, 2012; Yin, 2014). In other words, the data was broken down into components reflecting elements of the model of role interaction. In the initial list of codes, terms such as role expectation, role behaviour, role conflict, formal and informal sources were included. This was then extended to situations involved with role conflict such as the introduction of new technology or ambiguities within contracts. Two main strategies related to the objectives of the research were followed: the first strategy was concerned with formal and informal sources, which could be attributed to either role expectations or role behaviours. The second strategy was to explore instances involved with role conflict for construction participants.

Regarding sources, the aim was to explore elements to which participants were referring that shape and justify their expectations and behaviours. Based on participants' responses to different questions in interviews, the coding was developed further and other formal and informal sources were explored and included. This will be explained further in the Discussion section. 
Regarding the second strategy, eleven instances of role conflict were identified and analysed using the model of role interaction. Four instances will be presented here to illustrate the research process. Those instances were situations of role conflict for the facilities manager in the Green project, the architect and the mechanical engineer in the Yellow project and the architect in the Blue project. The reason as to why these four instances were chosen to present in this article was the very clear effect of informal elements on the development and emergence of role expectations and role behaviours of participants in those cases.

An example of the approach of analysis, the structuring, coding and handling of the data to build the several elements of the role interaction like a jigsaw puzzle is as followed: In the Green project, the associate project manager discussed BIM as the one issue particularly different from other projects in which he was involved. He explained the struggle and concerns of facilities manager (FM), should the project be handed over to the FM department as a 3D model in a BIM software package instead of the traditional way as operation and maintenance manual. The associate project manager also implicitly stated that the emphasis on BIM is through the head of the project. Through the initial analysis during the process of data collection, we captured the tension in one of the project meetings when the discussion moved to the subject of BIM. From there, we became more interested in exploring if the introduction of this technology to the project was one of the instances in which role conflict has happened/is happening. We made several notes from the meetings and identified the major roles involved in this discussion. From there, we then interviewed participants enacting those roles and raised the issue of BIM in the course of their interview.

The transcript of these interviews was first coded based on the concepts of organisational role theory such as role expectation, role behaviour, focal person and role 
senders. Then, we re-coded the minutes of previous project meetings based on the issue of BIM. At this point, the interview data, the minutes of the meetings, the observations made in the project meetings and participants' expressions all related to the subject of BIM was put together in a word document. It became an eight-page document that told everything about the story of implementing BIM in the Green project populated using several sources of the data. The document was compiled in a way that it explained the event chronologically.

At this point the suggested model of role process came into play with the aim of illustrating interactions between the focal person and the major role senders. To do so, we focused on several elements of the model such as the focal person, role sender/s, role expectations, role behaviours and even any negotiation and adjustment in roles due to the implementation of BIM in the project. It became clear that in this case, the focal person was the facilities manager and his major role sender was the head of the project. Role expectations of the head of the project were identified clearly along with its formal and informal sources. Misaligned role expectations or conflicting expectations with facilities manager's values and needs were identified and reflected in the model. This was then followed by the identification of facilities manager's role behaviour with his formal and informal sources. It became clear that the facilities manager faced role conflict in the process of BIM implementation. The case is illustrated in further details in the next section.

\section{Role conflict for a facilities manager (Green project)}

Implementing BIM in the Green project was associated with a degree of role conflict for the facilities manager. The head of the project in the client's organisation suggested, initially, that the Green project be delivered using BIM. He had quite a number of reasons for this argument. First he wanted to follow the government's mandate for 
collaborative BIM model/data drop as a minimum by 2016. His second argument was based on his very positive experience in the oil and gas industry. As he put it:

When I was in the chemical industry... we were doing 3D drawings 20 years ago. You looked at the 3D drawing and then right, I want information on that valve; click; information! Well, that is what BIM is talking about. (Head of the project, Green project)

Furthermore, there were some other elements in the Green project that, in his perception, made it an appropriate project for the introduction of BIM. The Green project was very much focused on the mechanical and electrical services, and the design of all mechanical, electrical as well as structural services was carried out by only one consultancy. The head of the project described this situation as a low number of interfaces between consultancies, which would then lead to fewer issues regarding responsibilities. Hence, from his point of view, the Green project, with its minimal interfaces between consultancies, was an ideal project for the use of BIM. Another motivation for him in this regard was related to the stakeholders of the Green project. As he explained, they were mostly his colleagues in the same building, mostly from facilities management (FM) department. Based on his previous experiences, some of the stakeholders from other departments were difficult to handle; whereas, this project was more self-contained. He was confident that, with the stakeholders in this project, fewer conflicting issues would be raised. All in all, he was convinced that the Green project was a good project to start experiencing BIM at that time. Although the initial design was carried out without the BIM model, consultancies on the project agreed to recreate the drawings based on a 3D model in BIM. Consultancies included the service in their fee proposals and it became a part of each of their contracts with the client. They produced the BIM model and presented it five months later in one of the project meetings. With the FM department, however, things became unexpectedly complicated. 
From the beginning, when BIM was mentioned, the facilities manager raised his concerns in relation to the handover process. From his point of view, this process should be reviewed carefully to avoid having a model or data which was of no value. He requested to be an integral part of the BIM review. As he described it, the FM department was "such an active running department" that there was no time to reorganize the whole lot. He was also concerned if proper software would be available within the department to view or edit the BIM model because even for widely used software like AutoCAD, the whole FM department owned only one licence. Furthermore, to use BIM, the facilities manager and his colleagues would need a fair amount of training and he could not see any prospect of this among the managers of the FM department. In addition, he was not motivated to change the current system. As he explained, in the FM department there was a web portal which would allow him to easily find the required manual. From his point of view, it would be a long time before the FM department could actually move away from Operations and Maintenance (O\&M) manuals. More importantly, he was not sure whether BIM would be useful for his department to carry out their daily tasks. In other words, he doubted how much they would actually use the information provided in the BIM model. He said:

\footnotetext{
A lot of the works we do, the guys actually go out and once they have done it and seen it, they will maintain it; a pump is a pump!" (Facilities manager, Green Project)
}

The whole situation put the facilities manager in a situation of role conflict. On the one hand, the design team in the Green project agreed to use BIM and there was an expectation, particularly communicated by the head of the project to the facilities manager to cooperate in this issue. On the other hand, he had some constraints and doubts. His situation could be examined using the model of role interaction. 


\section{The model of role interaction between facilities manager and the head of the project}

The head of the project's role expectation from the facilities manager was to agree with the implementation of BIM in the Green project and to prepare the FM department accordingly. Although the facilities manager did not have the ultimate authority to make decisions on these issues, he could potentially promote it in the department. As described above, the formal source for the head of the projects' role expectation was the government's policy regarding BIM, and his informal sources were his educational background, his work experience and the confidence he had in the cooperation of the stakeholders in the Green project.

The facilities manager's formal sources of role behaviour were the constraints over time and budget in the FM department. He was an employee within the client organization and did not have any contractual obligations to follow the head of the project's role expectation in the Green project. His informal sources of role behaviour were lack of motivation, doubts about the usefulness of BIM model and the lengthy process he was anticipating for moving from O\&M manuals. In this case, the facilities manager's formal and informal sources of role behaviour were not in line with the role expectation from the head of the project. This was a situation of role conflict for the facilities manager.

\section{Facilities manager's role behaviour}

As part of his role behaviour, the facilities manager questioned BIM and resisted a request made by the head of the project, which was to cooperate with the implementation of BIM. The tension in the project meetings was observed first-hand when the issue of BIM was discussed. This was probed for further in a subsequent interview, in which the head of the project said: 
Our maintenance colleagues are not so comfortable at this stage because this [BIM] is new for them. If they go and maintain they use a lot of paper, paper copy, PDF or on a CD ... dinosaur mentality ... projects come along with new things. What is interesting for a maintenance person is standardization. They would like every light to be the same; they just have to take that bulb out and put another one in. (Head of the project, Green project)

Eventually, after some months of discussions and negotiations among the project team, the head of the project slightly changed his perception. Indeed, the facilities manager brought up his concerns in several meetings until the head of the project agreed that some issues have to be solved. On being interviewed about this, the head of the project said:

\footnotetext{
What they [the FM department] are concerned about is ... if it is all electronic, how do we do it [the maintenance]? I don't think we have quite surely answered it yet, but if there was a computer terminal down there, or if they had an iPad for example, we don't know yet on that ... It is coming anyway, so they will just have to get used to it. But as a project we have a duty, responsibility, to hand over correct documentation to our maintenance department. And in the meeting ... it was me who said: I think we also need to have our standard documentation. (Head of the project, Green project)
}

So, as it was negotiated, the FM department would take over the project as per current practice as well as the 3D model and data. In this regard, the project manager had decided: "we will do both; we will pay for both". So, in this case, the situation of role conflict for the facilities manager was resolved by a dual handover of the output.

\section{Consequences and resolution of the situation of role conflict for the facilities manager}

Despite the tension over the use of BIM in the Green project, the facilities manager was quite confident throughout the meetings and discussions with the team. Indeed, his situation of role conflict caused less frustration for him than his role behaviour caused 
for the head of the project. One of the main reasons for his low level of stress was the power of the FM department; this department was one the most powerful departments within the client organization. He was quite confident that it was the head of the project and the designers who had to comply with his decisions in the course of the project, rather than the other way around.

An interpretation of this situation is that the formal and informal sources of role behaviour for the facilities manager were not strong enough to encourage or force him to cooperate in BIM. He was on the payroll of the client organization so there was not any inter-organizational contractual obligation, as a formal source, to force him to change. The motivation for potential future projects, as an informal source, did not have any place for him either. However, for consultancies who were contracted in, the client had included a fee in their contract to deliver the project in BIM. This was on top of their own motivation for a smoother design process and for keeping the client happy to receive further projects in the future.

\section{Role conflict for a senior electrical engineer (Yellow project)}

The hierarchical structure in the Yellow project was established by the method of contracting, ProCure21 (P21), a specific arrangement developed in the UK for health service projects commissioned by NHS Trusts. The principles of this method involve the contractor taking on responsibility for design and construction with a fixed supply chain of sub-contractors that was part of the process of selection for the framework. More specifically, a single multi-organization, known as a Principal Supply Chain Partner (PSCP), takes the responsibility for the design and construction phases. P21 is known as a framework arrangement because only a PSCP already in the framework may be used for a specific capital project. This enables longer-term relationships to be developed in the PSCP and with a small number of regular clients in order to encourage 
innovation and productivity savings.

In one of the stages of the selection process, the contractor company has to submit a list of consultancies, which will then become the framework consultancies, with the condition of the particular NHS Trusts' confirmation. P21 thus involves a clear set of hierarchical relationships: at the top sits the relevant NHS Trust, then the PSCP, followed by the framework consultancies, and then the rest of the supply chain. However, this hierarchy was changed by the client in the Yellow project, after the contractor brought his supply chain on board. This proved to have role implications for the designers, particularly the electrical engineer.

The main contractor in the Yellow project owned some of the supply chain companies including a mechanical and electrical engineering business (Company A). Although Company A was not a framework consultancy, with the involvement of the contractor's supply chain, it came on board. This, as the electrical engineer described, changed the initial hierarchy within the Yellow project. More specifically, Company A, as a part of the contractor's group, sat higher than the framework consultancies, where the electrical engineer was located. The electrical engineer explained that, in projects procured through general contracting, the first criterion for judging his own output would be the quality of the specified work and then the cost. However, in the Yellow project, which was not procured through general contracting, Company A pressured him to put cost ahead of quality. This was illustrated in the design of the low voltage (LV) distribution panel in which he had to interact with Company A.

Initially, the electrical engineer designed the LV distribution panel of the hospital in a way that, in the case of a power shut down, the hospital would remain fully operational. He argued that for a hospital building, he would want it to be easily maintained in such cases. According to him, this was a quality aspect of the design that 
he put ahead of the cost. His design was confirmed initially by the main contractor. But after the involvement of Company A, he was "under constant pressure to change the design to reduce the costs." As he explained, the mechanical and electrical (M\&E) design was just one of the packages with which the main contractor would deal. However, to Company A, "it was about every single element" of the M\&E design. So, he was pressured by this company to change the design of the LV distribution panel by reducing the resilience.

In the beginning, the electrical engineer refused to do so. His reasons were twofold: first, he did not want to put cost ahead of quality in his design. Second, the change order was from a company which should have been below his company in the hierarchy, if that company had not belonged to the main contractor's company. The interaction of Company A and the electrical engineer are examined below using the model of role interaction.

\section{The model of role interaction between Company $A$ and the electrical engineer}

Company A's role expectation from the electrical engineer was to change the LV distribution design to a more cost-effective alternative. Company A perceived itself as a part of the contractor body, so the formal source of their role expectation from the electrical engineer would be the contract between the main contractor and the consultancy for which the electrical engineer was working. The informal source for their role expectation was the value they placed on cost over quality. More specifically, Company A believed that there is no need for a hospital building to operate fully in the case of a power shut-down.

The electrical engineer's formal source of role behaviour was also his contract with the main contractor. Based on this formal source, he should respond positively to Company A's role expectation and apply all the changes in his design. Yet for him, 
there were some informal sources which were not encouraging him to do so. He gave value to the quality of his design rather than the cost of it. Furthermore, he felt uncomfortable making such a change when the change order was from a supply chain company - generally below him in the hierarchy. His case was an instance of role conflict.

\section{The electrical engineer's role behaviour}

Eventually, the electrical engineer's formal source of role behaviour, which was his contract with the contractor, led him to change the design of LV distribution panel. As mentioned, this was only one example of the many change orders that Company A ordered.

\section{Consequences and resolution of the electrical engineer's role conflict}

This was a very frustrating situation for the electrical engineer. Indeed, the issue was raised in the course of the interview as the very first answer to the question about the specifics of the Yellow project. His take on this situation was quite obvious. He felt very uncomfortable that the hierarchy was not the formal hierarchy within P21, in which consultancies sit above the supply chain. So, this case of role conflict was associated with a high level of personal cost. The architect and the structural engineer in the same project also complained about this situation in their interviews. The architect explained that the architectural and structural design was revised massively as a result of the changes within M\&E elements:

\footnotetext{
It was done as the revised M\&E design was developed ... That has been quite frustrating because the way that most practices work is you do things in a managed sequence, like the RIBA Stages of work. It is not particularly cost effective for us to go back at a later stage and make incremental changes. (Architect, Yellow project)
} 
He took the view that if the supply chain had been brought on board earlier, designers could have made sure that "they [the supply chain] were buying into the scheme". He speculated about the reason of the late involvement of the supply chain and said that "there were a lot of uncertainties up till Stage D about whether the project would even go ahead. So, there was a reluctance to commit time and resource to it [from the contractor side]."

In short, the specific hierarchical structure of the Yellow project, in which the M\&E supply chain sat above the consultancies, led to role conflict for the designers, particularly the electrical engineer. The hierarchical structure of the project came into play as an informal source of role behaviour for the project participants. It was not based on the general contractual relationships in a P21 project and, subsequently, had role implications for some designers.

\section{Role conflict for an architect (Yellow project)}

One of the tasks of the designers in the Yellow project was to check the detail drawings produced by sub-contractors, to ensure that they were compliant with the original design specifications. Carrying out this task led to role conflict for the designers, particularly the architect, to the extent that he described it as a "painful task". In the same context, the regional design manager, in the contractor company, stated that "they [designers] go through a bit of a phase really".

After the design was developed, it was sent to the relevant sub-contractors who then produced the detail drawings. However, since the responsibility for the design was with the designers, they had to check all the drawings to ensure that detail drawings were based on the original design. This was a part of their contractual obligation. The architect believed that there was a tendency among sub-contractors to change some of the specifications to make savings in a clever way; a type of change that did not need 
the client's approval. To prevent such thing from happening, he had been checking 800 cladding drawings - developed by the cladding sub-contractor-for several months. During interview, he said:

We get quite a lot of cladding details that might look OK on the face of it, but actually, if you scrutinized in any detail there would be some leakage in terms of air-tightness and water-tightness. (Architect, Yellow project)

It was as a very time-consuming and painful task. Yet, as he described, part of the frustration was due to the type of the work he had to carry out. He took the view that his role, as an architect, was not "ideal" in the Yellow project. On the one hand, he had to check every single drawing to make sure that the quality was not compromised and the system performed in the way that it was originally designed. On the other hand, he believed that his task should be "designing, not checking". This led to role conflict for him.

\section{The model of role interaction for the architect}

The situation of role conflict for the architect can be examined using the model of role interaction. Generally, the interaction was between him and the main contractor. The contractor's role expectation from the architect was to approve the drawings produced by sub-contractors. The formal source for the contractor's role expectation was the contract between the contractor and the architectural company. The formal source of the architect's role behaviour was also the same document. His informal source of role behaviour was his background and previous experiences; he believed that the task of the architect was to design architectural elements rather than to check detail drawings of the supply chain. There was misalignment between the contractor's role expectation and the architect's informal source of role behaviour. 


\section{Architect's role behaviour}

Eventually, the architect carried out all the checking because of his contractual obligation. In other words, his role behaviour was based on his formal sources rather than informal sources of role behaviour.

\section{Consequences and resolution of the architect's role conflict}

The personal cost of the architect's role conflict was the inner tension as to what his tasks should have been compared to what he was doing.

\section{Role conflict for an architect (Blue project)}

The Blue project was to open a new bank branch in an area of the South-East of UK. According to the architect, the building that was selected for this branch did not have a big space but the client expected him to fit as many positions and machines as possible. This conflicted with the architect's interests and led to role conflict for him.

The client's program to develop their branches was based on several factors including their statistical investigations and marketing strategies. One of those generic criteria was the space that was needed to design a certain amount of equipment (e.g. internal automatic teller machines (ATMs), desk positions). However, in the Blue project, the most suitable place that was found after two years of searching the area did not have the space to fit all the equipment and positions specified in the client's brief. The architect said:

One thing that we have [is that] they [the client] will try to put as much equipment and as many positions as possible because, obviously, it is retail so they are paying a high price for the rental so they want to save as much as possible. But they only have this amount of physical space. So, as a designer they want you to create an environment that is inviting, but at the same time they are giving you numbers that are going to make it claustrophobic (Architect, Blue project). 
The architect explained that each desk represented a sale procedure and, obviously, potential profit. Therefore, it was in the interest of the bank to fit a high number of desks and machines. At the same time, they would like to have a space in which their employees and customers would feel comfortable and not constrained. As he put it, the client expected him to do two "contradictory things".

The architect's perception of his role was to be in the favour of a better layout rather than "having to meet the brief". As he explained in the interview, it was his task, as an architect, to make the design as nice as possible and it was the client's task to try to fit as much equipment as possible because they wanted money out of it. At the same time, he explained how tricky it was to communicate a "no", particularly to a "really important" client like the one for this project; as a client "they have this element of they are always right." The whole situation caused role conflict for the architect.

\section{The model of role interaction between the architect and the client}

In this case, the client had two contradictory role expectations from the architect. Their first role expectation was to fit as many desks as possible in the branch. Their formal source for this role expectation was the client's brief, and their informal source was their customary financial motivation to make as much money as they could out of the branch.

The second role expectation from the architect was to create an inviting and comfortable environment for their employees as well as their clients. For this role expectation the client had an informal source which was the value given to the comfort of the people in the branch. Interestingly, even though the formal and informal sources of client's role expectations were not in line with each other, the client did not face role 
conflict. Instead, they developed two contradictory role expectations and communicated them to the architect.

The architect's formal source of role behaviour was the client's brief. His informal source was the value he was giving to the architectural aspects of his design. In this case, his informal source of role behaviour conflicted with one of the client's role expectations. In addition, he faced two misaligned role expectations from the client.

\section{Architect's role behaviour}

The architect initially tried to fit as many desks as possible but, as he put it, he also had to "draw a line somewhere". His informal source of role behaviour - the value he was giving to the architectural design - was more influential in his decision than the formal source; the client's brief. At the early stages of the project, he informed the client that, physically, there was not enough space to fit that number of desks in the branch. A special meeting was set up in the client's organization and the issue was discussed in more detail. The architect presented his design and explained why he could not fit more desks in. His primary argument was the client's second role expectation, which was to design a comfortable area for the employees and the customers in that branch:

I told them: 'but look at this [the design], you are going to have a very nice branch and people are going to be looking at it. It is going to improve your presence [here]' (Architect, Blue project).

After several meetings, the architect managed to persuade the client that his design was the optimum layout.

\section{Consequences and resolution of role conflict}

In this case, the architect's informal source of role behaviour was in line with one of the client's role expectations, and this helped him to negotiate the case. As a result, he did 
not feel very frustrated and the case did not involve a high level of personal or organizational cost. In a similar context, but more generally, he commented on some of the client's requests:

For instance, you have an idea of the budget that they have for a particular project, and when they start telling you what they want to do in that branch, you start making numbers in your mind and think there is going to be structural work, there is going to be planning application. You can see everything that can go wrong and how it is impossible. (Architect, Blue project)

To sum up, the architect's perception of his tasks and the client's mismatched role expectation led to role conflict for the architect. Interestingly in this situation, the architect's informal source of role behaviour was in line with one of the client's role expectation. This helped him to resolve the situation with some negotiations with the client.

\section{Discussion}

The analysis showed that if the focal person is in a position to influence the formal elements in favour of his or her informal elements, then he or she may still face role conflict but will experience less frustration in such situations. Among the four instances presented here, this was the case for the facilities manager in the Green project and the architect in the Blue project. However, if the focal person is to follow formal elements that are not in line with his/her informal elements, then frustration may result from the role conflict. In other words, in the instances studied here at least, the formal trumps the informal.

The facilities manager influenced the nature of the output from the documentation stage of the Green project to ensure that it was delivered not only as a BIM 3D model, but also in the form of traditional O\&M manuals. In the case of the 
architect in the Blue project, the formal project brief included a certain number of desks in the bank building, which was too high for the space in the building, from the architect's perspective. Coupling his value for the architectural design with the client's desire to have an inviting space for the customers, he managed to negotiate the number of desks in the building. In both cases, the focal person didn't feel much frustrated or stressed in the instance of the role conflict. Indeed, the case was resolved with the adjustment of the role senders' expectations. However, in the Yellow project, both the electrical engineer and the architect had no choice but to conform to the expectations of the role senders; to follow the contractual obligations set by the contractor. The two latter cases suggest that the frustration to enact a role (along the lines referred to by Gluch 2009) is not limited to the new roles but also relevant for the more established roles such as architects and electrical engineers. Indeed, the specific formal and informal practices of each project are influential on individuals in enacting their roles. As mentioned in the theoretical background, Katz and Kahn (1978) and Raphael (1965) suggested that an informal, flexible and autonomous work environment would reduce the negative impacts of role conflict. In contrast, Kahn et al. (1964) and Rizzo et al. (1970) suggested that a more formalized organization would be the answer. Although, there is not unique, universal answer to this dilemma, the cases studied in this research illustrate clear formal expectations, in a flexible and autonomous environment, will be less likely to lead to the emergence of disruptive situations of role conflict.

The literature review suggests the formal elements as contracts, duties and deliverables, fee issues, formal policies, plan of work, rewards and penalties and informal elements as interpersonal relationships, motives, values, interests and fears (Kahn et al 1964, Kabiri et al 2014 and Gluch 2009). The analysis in this research showed that contracts, more than anything else, tended to be the formal source of role 
expectation and role behaviour that was referred to in the interviews. Such references to contracts appeared either in the form of contract obligations or fee limits that were set for a particular agreement. The analysis in this research extended the formal elements to government policies, participant's role profile in the company and the client's brief as formal elements, informing participants' expectations and behaviours. As for informal sources, the most recurrent ones in the analysis were the individual's values and interests. In addition, the informal hierarchy, doubts about the benefits of the technology and the fear of upsetting the client were further informal elements emerged from the above four cases.

As for the consequences of role conflict, previous research revealed that this phenomenon is associated with several negative consequences such as frustration, inner conflict, job tension and employee burnout for the focal person (Kahn et al. 1964; Jackson and Schuler 1985; Netemeyer Johnston and Burton 1990; Van Sell 1981; Tang and Chang 2010). The finding of this research partly confirms the results of those studies by demonstrating interactions in which the focal person finds the situation awkward, difficult to handle and frustrating.

However, three further observations were also made. First, in some instances the focal person did not have a very negative experience. This was primarily in the cases where the focal person was able to negotiate the role expectation of the role senders in the favour of his own values and interests. The second observation was that, depending on the role behaviour of the focal person, the interaction might be involved with frustration for the role sender. This was apparent in the case of the facilities manager where the head of the project, as the role sender, was very frustrated due to the role behaviour of the facilities manager. 
Kahn et al. (1964) attributed the situations of role conflict and their consequences, at the top level, to the rapid changes in the technology and the complexity of the organisations. As the third observation, evident in this research as a whole, and presented in one of the cases, the introduction of new technologies is still a platform involved with role conflict for individuals who are engaged with the implementation of those technologies. And, in these instances, both formal and informal sources contributed to the success or failure of the situation.

\section{Conclusions}

This research dealt with one of the main limitations of organisational role theory. The theory does not explain how expectations and behaviours come to be what they are and how roles are socially constructed. As a contribution of the current research to organisational role theory, formal and informal sources of expectations were included and several examples emerged from literature review and the case studies were identified. Aspects such as stereotyping or individuals' understanding of their role is embedded within the social recognition of the role influencing the formation of expectations and behaviours within organisational context. Taking into account formal sources enables the study of how roles are institutionally governed and how elements such as contracts and plans of work define them. Including informal sources allows for the idea that some of the aspects of the role, even in the context of work role, are socially constructed. In this way, organisational role theory is extended to deal with informal and formal aspects.

The model of role interaction was presented and used to demonstrate four different situations of role conflict in construction project organisations. The model proved to be a very helpful tool first to disentangle formal and informal elements that shaped and 
influenced role expectations and role behaviours and second to extend the initial list for a better reflection of interactions in construction projects. While the original focus of organisational role theory (Kahn et al. 1964, Gross et al. 1958, Katz and Kahn 1978) was on the individual and psychological aspects of role dynamics, the model of role interaction allows a systematic and asymmetric analysis of participants' interactions while studying formal and informal sources of role expectation and role behaviour.

The UK government and several institutions have developed numerous guidelines and documents to define roles and responsibilities and to place emphasis on more collaborative attitudes and behaviours with the aim of improving cooperation and increasing integration among construction participants. Some of the findings from the research reported here indicate that there may be more chance of promoting collaboration by clarity on formal expectations and, at the same time, depending on informal elements of construction industry. In other words, participants are less likely to be collaborative and more frustrated, if we depend more and more on formality. Piling on more formality decreases the likelihood of collaboration.

The model of role interaction offers a tool for a systematic analysis of role interactions while taking into account multiple formal and informal elements that informing participants' expectations and behaviours. Future research could involve case study research on a number of projects in which new technology is introduced. In addition, drawing on the model of role interaction, research that specifically focuses on the process of sending and receiving role expectations and role behaviour will make a contribution to the general topic of communication and role interactions.

\section{Acknowledgement}

We would like to thank Dr. Libby Schweber for her exceptional guidance, priceless advice and consistent encouragement. We would also like to thank the Faculty of 
Science and the School of Construction Management and Engineering at University of Reading for providing the research grant, which funded the first author's $\mathrm{PhD}$ studies.

\section{References}

Ahmady, S. et al. (2007) 'Organizational role stress among medical school faculty members in Iran: dealing with role conflict.', BMC medical education, 7, p. 14.

Biddle, B. J. (1986) 'Recent development in role theory', Annual Review of Sociology, 12, pp. 67-92.

Bresnen, M. (2009) 'Living the dream? Understanding partnering as emergent practice', Construction Management and Economics, 27(10), pp. 923-933. doi:

10.1080/01446190902974145.

Bryman, A. (2012) Social research methods. 4th editio. New York: Oxford University Press Inc.

Callero, P. L. (1994) 'From Role-Playing to Role-Using: Understanding Role as Resource', Social Psychology Quarterly, p. 228.

Dainty, A. R. J., Green, S. D. and Bagilhole, B. M. (2007) People and culture in construction: A reader. London: Taylor \& Francis.

Diebig, M., Bormann, K. and Rowld, J. (2017) 'Day-level transformational leadership and followers' daily level of stress: a moderated mediation model of team cooperation, role conflict, and type of communication', European Journal of Work and Organizational Psychology, 26(2), pp. 234-249.

Floyd, S. W. and Lane, P. J. (2000) 'Strategizing throughout the organization: managing Role conflict in strategic renewal', Academy of Management Review, 25(1), pp. 154177.

Georg, S. and Tryggestad, K. (2009) 'On the emergence of roles in construction: the qualculative role of project management', Construction Management and Economics, 27(10), pp. 969-981.

Goffman, E. (1959) The Presentation of Self in Everyday Life, Teacher. Edited by E. University Of. Doubleday (Anchor books). doi: 10.2307/2089106.

Gottlieb, S. C. and Haugbølle, K. (2013) 'Contradictions and collaboration: partnering in-between systems of production, values and interests', Construction Management and 
Economics, 31(2), pp. 119-134. doi: 10.1080/01446193.2012.756141.

Gross, N., Mason, W. S. and McEachern, A. W. (1958) Explorations in role analysis: studies in the school superintendency role. New York: Wiley.

Jackson, S. E. and Schuler, R. S. (1985) 'A meta-analysis and conceptual critique of research on role ambiguity and role conflict in work settings', Organizational Behavior and Human Decision Processes, 36(1), pp. 16-78.

Kabiri, S. (2015) Role conflict and role ambiguity in construction projects. University of Reading, Reading.

Kabiri, S., Hughes, W. and Schweber, L. (2014) 'Role conflict in project team dynamics', in 30th Annual ARCOM Conference, pp. 875-84.

Kahn, R. L. et al. (1964) Organizational Stress: Studies in Role Conflict and Ambiguity. New York: John Wiley \& Sons.

Katz, D. and Kahn, R. L. (1978) The Social Psychology of Organizations. John Wiley \& Sons.

King, N. (1998) 'Template analysis', in Symon, G. and Cassell, C. (eds) Qualitative methods and analysis in organizational research. London.

King, N. (2012) 'Doing template analysis', in Symon, G. and Cassell, C. (eds) Qualitative organizational research: Core methods and current challenges. London. Lee, R. T. and Ashforth, B. E. (1996) 'A meta-analytic examination of the correlations of the three dimensions of job burnout', Journal of Applied Psychology, 81, pp. 123133.

Lynch, K. D. (2007) 'Modeling Role Enactment: Linking Role Theory and Social Cognition', Journal for the theory of social behaviour, 37(4), pp. 379-399.

Mangham, I. L. (2005) 'Vita Contemplativa: The Drama of Organizational Life', Organization Studies, 26(6), pp. 941-958.

Mueller, J. (2015) 'Formal and informal practices of knowledge sharing between project teams and enacted cultural characteristics', Project management Journal, 46(1), pp. 5368. doi: 10.1002/pmj.

Netemeyer, R. G., Johnston, M. W. and Burton, S. (1990) 'Analysis of role conflict and role ambiguity in a structural equations framework', Journal of Applied Psychology, 
75(2), pp. 148-157.

Nixon, A. E. et al. (2011) 'Can work make you sick? A meta-analysis of the relationships between job stress and physical symptoms.', Work \& Stress, 25, pp. 1-22.

Piko, B. F. (2006) 'Burnout, role conflict, job satisfaction and psychosocial health among Hungarian health care staff: A questionnaire survey', International Journal of Nursing Studies, 43(3), pp. 311-318.

Raphael, E. E. (1965) 'Power Structure and Membership Dispersion in Unions', American Journal of Sociology, 71(3), pp. 274-283.

Rommetveit, R., 1955. Social norms and roles, Minneapolis: University of Minnesota Press.

Rizzo, J. R., House, R. J. and Lirtzman, S. I. (1970) 'Role Conflict and Ambiguity in Complex Organizations', Administrative Science Quarterly. Johnson Graduate School of Management, Cornell University, 15(2), pp. 150-163. doi: 10.2307/2391486.

Schreyägg, G. and Häpfl, H. (2004) 'Theatre and Organization: Editorial Introduction', Organization Studies, 25(5), pp. 691-704.

Van Sell, M. (1981) 'Role Conflict and Role Ambiguity: Integration of the Literature and Directions for Future Research', Human Relations, 34(1), pp. 43-71. doi: 10.1177/001872678103400104.

Seymour, D. and Rooke, J. (1995) 'The culture of the industry and the culture of research', Construction Management and Economics, 13(6), pp. 511-523.

Soltani, I. et al. (2013) 'Investigating the effect of role conflict and role ambiguity on employees' job stress :Articulating the role of work-family conflict', Management Science Letters, 3(7), pp. 1927-1936.

Tang, Y. and Chang, C. (2010) 'Impact of role ambiguity and role conflict on employee creativity', African Journal of Business Management, 4(6), pp. 869-881.

Teh, P.-L. et al. (2009) 'Does total quality management reduce employees' role conflict?', Industrial Management \& Data Systems, 109(8), pp. 1118-1136. doi: $10.1108 / 02635570910991337$.

Tuuli, M. M., Rowlinson, S. and Koh, T. Y. (2010) 'Control modes and mechanisms in construction project teams: drivers and consequences', Construction Management and 
Economics, 28(5), pp. 451-465. doi: 10.1080/01446191003702500.

Uetschy Murfield, M. L. et al. (2016) 'Supplier Conflict: An Investigation of its relational implications and impact on supplier accommodation', Journal of Business Logistics, 37(2), pp. 168-184.

Wickham, M. and Parker, M. (2007) 'Reconceptualising organisational role theory for contemporary organisational contexts', Journal of Managerial Psychology, 22(5), pp. 440-464.

Yin, R. K. (2014) Case Study Research: designand methods. California: Sage Publications, Inc. 